TITLE:

\title{
Inhibition of MCP-1/CCR2 pathway ameliorates the development of diabetic nephropathy(Abstract_要 旨)
}

$\operatorname{AUTHOR}(\mathrm{S}):$

Kanamori, Hiroshi

\section{CITATION:}

Kanamori, Hiroshi. Inhibition of MCP-1/CCR2 pathway ameliorates the development of diabetic nephropathy. 京都大学, 2008, 博士(医学)

ISSUE DATE:

2008-01-23

URL:

http://hdl.handle.net/2433/135787

RIGHT: 


\begin{tabular}{|c|c|}
\hline 名 & 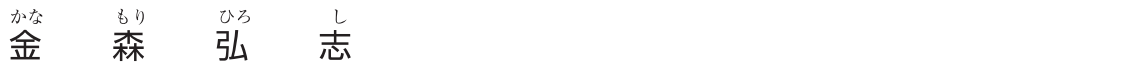 \\
\hline 学位 (専攻分野) & 士（医 \\
\hline 学 位 記 番 号 & 医 博 第 3167 号 \\
\hline 学位授与の日付 & 平成 20 年 1 月 23 日 \\
\hline 学位授与の要件 & 学位規則 第 4 条第 1 項該当 \\
\hline 咞究科 · 専攻 & 医 学研 究科内科系専 攻 \\
\hline 位論文題目 & $\begin{array}{l}\text { Inhibition of MCP-1/CCR2 pathway ameliorates the development of } \\
\text { diabetic nephropathy } \\
\text { (MCP-1/CCR2 経路の抑制は糖尿病性腎症の進展を改善する) }\end{array}$ \\
\hline
\end{tabular}

論文調査委員教主授查) 塪暢也教授中尾一和教授小川修

\section{論文内容 の 要旨}

末期腎不全にて透析療法を受けている患者は本邦では扰よそ 25 万人にも達し、透析導入原疾患の $40 \%$ 占める糖尿病性 腎症の進行を抑制することは急務である。この疾患の特徵として、その終末像である糸球体硬化が挙げられるが、これは糖 尿病性腎症の最む重要な構造的変化である。

糖尿病性腎症の糸球体硬化の成因機序として、遺伝的背景による発症因子と、終末糖化産物（AGE）や全身性・糸球体高 血圧、アンギオテンシン II、TGF- $\beta$ 年よ゙の増悪進展因子により、メサンギウム細胞が形質転換を起こし 4 型コラーゲン （Col4）に代表される細胞外基質を過剩産生しているというあのである。近年、アンギオテンシン变換酵素阻害剤やアンギ オテンシン II 受容体拮抗薬 (ARB) に糖尿病性腎症の進行遅延効果が示されているが、同疾患による透析導入が増加の一途 である現状では対策は不十分と言わざるを得ず、より本態に迫る成果が必要である。

最近この増悪因子の一つとしてマクロファージの関与が注目を集めている。一方、マクロファージの浸潤においては MCP-1（monocyte chemoattractant protein-1）が、その受容体 CCR2 を介し重要な役割を果たしていることが、動脈硬化 や腎炎において報告されている。MCP-1 は糖尿病性腎症の比較的早期において糸球体や間質での発現が増加していることは 報告されているが、糖尿病性糸球体硬化における MCP-1/CCR2 経路の役割の解明は不十分である。従って本研究の目的は、 糖尿病性腎症の進展に MCP-1/CCR2 経路が果たす役割を明らかにし、治療法への応用の可能性を追求することである。

そこで本研究では 1 型糖尿病性腎症のモデルである、膵 $\beta$ 細胞で 2 型一酸化窒素 (NOS2) を過剩発現するトランスジェ ニックマウス（iNOS-Tg）を用い検討した。このモデルマウスでは、4 週齢で高血糖を示し、16 週齢で顕著な糸球体硬化を 呈する。4 週齢の糖尿病マウスおよび野生型マウスに CCR2 拮抗薬であるプロパゲルマニウムを含む食餌を与えることによ り、MCP-1/CCR2 経路の抑制効果をみた。また、プロパゲルマニウムによる効果を確認するため、同じく4 週齢のマウス に MCP-1 のドミナントネガティブ変異体である 7ND 発現プラスミド $100 \mu \mathrm{g}$ を 週ごとに遺伝子導入し、MCP-1による シグナルを特異的に抑制した。糸球体硬化の指標として、メサンギウム基質の拡大を PASM 染色陽性領域で評価した。12 週後、糸球体の PASM 陽性領域、F4/80（および CD68）陽性マクロファージ数、Col4、TGF- $\beta$ 1 陽性領域を計測した。同 時に糸球体の MCP-1 発現も測定した。

糖尿病マウスの糸球体における MCP-1 mRNA 発現は野生型に比べおよそ 2 倍に増加していた。糸球体 PASM 陽性領域 やF4/80 陽性マクロファージは、野生型に比べ糖尿病マウスでそれぞれ 2.3 倍、10.9 倍に増加していたが、プロパゲルマニ ウムによりそれぞれ $52 \%$ 、86\%抑制された。糖尿病マウスにおける糸球体 PASM 陽性領域や F $4 / 80$ 陽性マクロファージの 増加は、プロパゲルマニウム投与と同様、7ND 投与によってもそれぞれ $46 \% 、 83 \%$ 抑制された。また、糖尿病マウスで認 められた糸球体 Col4、TGF. $\beta_{1}$ 発現の増加む有意に抑制された。

本研究により、糖尿病性腎症の糸球体硬化における MCP-1/CCR2 経路の役割が示唆された。このことは、MCP-1/CCR2 経路が糖尿病性腎症の進展における新たな治療標的である可能性を示す。 
糖尿病性腎症は、末期腎不全にて透析に至る第一の疾患である。したがって、その終末像である糸球体硬化への進展機構 の解明が重要である。近年、糖㽷病性腎症の増悪因子の一つとしてマクロファージの関与が注目を集めている。本研究にお いては糖尿病性腎症のモデルマウスを用いて、実際の生体内で糸球体硬化におけるマクロファージおよびその走化因子であ る MCP-1、MCP-1 の受容体 CCR2 の役割を検討した。この結果、MCP-1 は糖尿病マウスの糸球体中で発現が克進してお り、糸球体硬化領域や糸球体浸潤マクロファージも糖尿病マウスで増加していたが、これら硬化領域や浸潤マクロファージ は CCR2 アンタゴニストであるプロパゲルマニウム、あるいは MCP-1 のドミネントネガティブ変異体である 7ND 投与に よって抑制されることを示した。さらには糖尿病マウスで認められた糸球体 4 型コラーゲン、TGF- $\beta_{1}$ 発現の増加む抑制さ れていた。以上より、MCP-1/CCR2 経路は糖尿病性腎症の進展に重要な役割を持っていることを証明した。

以上の研究は、糖尿病性腎症において糸球体硬化の鍵となる成因機構を生体で明らかにしたもので、糖尿病性腎症進展機 構の解明に貢献し、治療への応用に寄与するところが大きい。したがって、本論文は博士（医学）の学位論文として価值あ るものと認める。

なお、本学位授与申請者は、平成 19 年 10 月 30 日実施の論文内容とそれに関連した試問を受け、合格と認められたもの である。 